doi: $10.15407 /$ ujpe62.05.0422

R. VISHWAKARMA ${ }^{1,2}$

${ }^{1}$ Advance Thin Film Laboratory, Department of Physics \& Electronics,

Dr. Ram Manohar Lohia Avadh University

(Faizabad (UP) India)

${ }^{2}$ RPS Degree College

(Mahendergarh, (MDU Rohtak) Haryana; e-mail: rhl.jaunpur@gmail.com)

THICKNESS-DEPENDENT STRUCTURAL,

PACS 81.07.-b, 81.05.Ea 73.61.Ga

\title{
ELECTRICAL, AND OPTICAL PROPERTIES OF ZnS THIN FILMS DEPOSITED BY THERMAL EVAPORATION
}

\begin{abstract}
Zinc sulfide $(\mathrm{ZnS})$ thin films are deposited onto an ultrasonically clean glass substrate, by using the thermal evaporation technique at room temperature. The film thickness was varied in the range from $400 \mathrm{~nm}$ to $1300 \mathrm{~nm}$. The X-ray diffraction (XRD), scanning electron microscopy (SEM), and energy dispersive analysis of X-rays (EDAX) are used to characterize the structural properties of films. The electrical and optical properties of films are characterized with a dc two-point probe, the Hall effect, and ultra-violet visible absorption spectra. The XRD spectra indicate that the thin films have polycrystalline nature and possess the cubic structure with (111) preferential orientation. The diffraction patterns are sharpen with increase in the film thickness. Scanning electron microscope data disclose that the films have nanograins approximately $97.89 \mathrm{~nm}$ in size. A reduction in the resistivity shows that the films are semiconductors in nature. For a film thickness of $1200 \mathrm{~nm}$, the maximum mobility is $26.03 \times 10^{1} \mathrm{~cm}^{2} / \mathrm{Vs}$, minimum resistivity is $0.08 \times 10^{6}(\mathrm{Ohm} \cdot \mathrm{cm})$, and band gap is $3.26 \mathrm{eV}$. The film thickness has been optimized on the basis of the observed properties.
\end{abstract}

Ke y words: ZnS films, grain size, dislocation density, electrical resistivity, band gap, activation energy, electron mobility.

\section{Introduction}

Now, semiconducting nanoparticles have become the backbone for the growing interest in nano-science and technology due to their crucial role in devices. Nanocrystalline zinc sulfide $(\mathrm{ZnS})$ belongs to the II-VI family of semiconducting materials with a large direct band gap $(3.72-3.77 \mathrm{eV})$ in the near UV region. The zinc sulfide semiconducting material has been used in the fabrication of many optoelectronics devices, because of its unique properties such as the quantum size effect [1-2] and the abnormal luminescence phenomenon [3-5]. $\mathrm{ZnS}$ is a potentially important material for antireflection coatings and window layer materials in heterojunction solar cells [6]. The non-stoichiometry is responsible for the conductivity in thin films, which is created during the deposition of a thin film. In the recent years, advances in the formation of nano-sized materials are continuously unabated, and it was shown

(c) R. VISHWAKARMA, 2017

422 that the more exciting opportunities arise, if the size of a crystal structure can be scaled down to nanometers. These wide-band-gap materials are suitable for the use in blue-light emitting diodes [7], optoelectronics devices such as electron luminescent displays $[8,9]$ and cathode luminescent displays [10], and in bioelectronics [11]. ZnS semiconductor exists in two phases, i.e. the cubic phase (sphalerite) and hexagonal phase (wurtzite). In the fabrication of optoelectronics devices, we need high conductivity, high mobility, and low band gap. Many growth techniques have been adopted to prepare $\mathrm{ZnS}$ thin films, such as the sputtering [12], pulsed-laser deposition [13], metal organic chemical vapor deposition [14-17], electron beam evaporation [18], photochemical deposition [19], chemical bath deposition [20], and thermal evaporation technique [21]. Among these methods, the thermal evaporation technique is of the highest interest, because the advantages of this technique are high stability, reproducibility, high deposition rate, large area deposition, and non-expansiveness. This tech-

ISSN 2071-0194. Ukr. J. Phys. 2017. Vol. 62, No. 5 
nique provides the economical efficient use of an evaporate material enabling the constant rate of deposition. In the present study, we prepared $\mathrm{ZnS}$ thin films, by using the thermal evaporation technique. The effect of film thickness on the structural, electrical, and optical properties of films has been investigated. We also studied its variation with film thickness keeping room temperature and also optimized the film thickness.

\section{Experimental}

\subsection{Chemicals and substrate cleaning}

For the preparation of semiconducting $\mathrm{ZnS}$ thin films, all chemicals, which have high purity $99.99 \%$, were purchased from Alfa Aesar, USA. The substrate cleaning plays an important role in the deposition of thin films, so commercially available glass substrates with a size of $75 \mathrm{~mm} \times 25 \mathrm{~mm} \times 1 \mathrm{~mm}$ were washed in a detergent, then in chromic acid and in doubly distilled water in an ultrasonic cleaner, and dried at $400 \mathrm{~K}$ in an oven.

\subsection{Preparation of $\mathrm{ZnS}$ thin films}

The nanocrystalline $\mathrm{ZnS}$ thin films of different thicknesses of 400-1300 nm were deposited on well cleaned glass substrates at room temperature, by using the thermal evaporation technique. The thin films were fabricated under vacuum of $10^{-4}-10^{-5}$ Torr. The zinc sulfide was used as a source material. The stoichiometric starting/source materials $(\mathrm{ZnS})$ were taken in a molybdenum boat and evaporated in vacuum $\left(\sim 10^{-5}\right.$ Torr $)$ in the vacuum system equipped with a liquid nitrogen trap. The source materials have kept at the distance of $120 \mathrm{~mm}$ from the substrate holder in a vacuum chamber. The film deposition rate (2.0-15 $\mathrm{nm} / \mathrm{s}$ ) was adjusted by changing the electrical current. The deposition rate was measured by a digital film thickness monitor, by using a quartz crystal sensor set at $6 \mathrm{MHz}$ (DTM-10). Initially, the substrates were not exposed to a vapor stream by using a shutter. After obtaining the constant rate of evaporation, the shutter was opened. During the deposition of a thin film, the substrate was placed normally to the line of sight from the evaporation surface at different polar angles to obtain the uniform deposition. The source material about $30 \mathrm{mg}$ in weight was used for the deposition of each thin film. In each cycle of deposition, the fresh source material was kept in a molybdenum boat. The film thickness and the deposition rate were measured by a film thickness monitor (FTM, VICO, DTM-10) with a quartz crystal sensor vibrating at a frequency of $6 \mathrm{MHz}$. The sensor of FTM was attached in parallel to the substrate. The substrate temperature was measured, by using a digital temperature meter (PTS-9601: GELCO) with a thermocouple sensor. The tip of the thermocouple sensor was in contact with the substrate surface. The different substrate temperatures were obtained by changing the current of a substrate heater.

\section{Characterization of Thin Films}

\subsection{Structural characterization}

The XRD patterns of deposited thin films were recorded by a Rigaku diffractometer, by using graphite-filtered $\mathrm{CuK} \alpha_{1}$ radiation $(\lambda=1.54 \AA)$ at $40 \mathrm{kV}, 100 \mathrm{~mA}$ with a scanning rate of 3 degree per minute $\left(2 \theta=20^{\circ}\right.$ to $\left.60^{\circ}\right)$. The composition of deposited films was analyzed, by a using scanning electron microscope with an attached EDAX (Energy Dispersive Analysis of X-rays) unit. The surface morphology of thin films was studied by scanning electron microscopy. The crystallite size and the dislocation density of deposited thin films were calculated, by using the Debye-Scherrer formula [22]

$D=\frac{0.94 \lambda}{\beta \cos \theta}$,

Dislocation density $=\frac{1}{D^{2}}$,

where $D$ is the grain size or crystal size, $\lambda$ is the wavelength of radiation used, $\theta$ is the diffraction angle of the concern diffraction peak, and $\beta$ is the full width at half maximum (FWHM) of the diffraction peak corresponding to a particular crystal plane.

\subsection{Electrical characterization}

The electrical resistivity, conductivity, and electron mobility of semiconducting $\mathrm{ZnS}$ thin films were measured, by using the dc two-point probe method and the Hall effect measurement. The electrical resistivity, conductivity, and electron mobility of thin films were determined by the following relations [23]:

$$
\begin{aligned}
& \rho=\rho_{0} \exp \left(\frac{E_{0}}{K T}\right), \\
& \mu=\frac{R_{\mathrm{H}}}{\rho},
\end{aligned}
$$


where $\rho$ is the resistivity, $K$ is the Boltzmann constant, $T$ is the absolute temperature, $\mu$ is the mobility, and $R_{\mathrm{H}}$ is the Hall coefficient.

\subsection{Optical characterization}

The optical absorption spectra were recorded by a Shimadzu double-beam double monochromator spectrophotometer (UV-2550) in the wavelength range 200-600 nm at room temperature with unpolarized radiation on thin films, which were deposited on a glass substrate of different film thicknesses at room temperature. The absorption coefficient $(\alpha)$ was calculated for a deposited thin film in the region of strong absorption, by using the relation [24]

$\alpha=\frac{1}{d\left\{\ln \left(\frac{1}{T}\right)\right\}}$,

where $\alpha$ is the absorption coefficient at a particular wavelength, $T$ is the transmittance at the same wavelength, and $d$ is the film thickness.

The direct band gap of a thin film is calculated, by using the Tauc relation [23]

$\alpha h \nu=A\left(h \nu-E_{g}\right)^{n}$,

where $h \nu$ is the photon energy, $E_{g}$ is the band gap, $A$ is a constant, and $n=1 / 2$ for a direct-band-gap material.

\section{Results and Discussion}

\subsection{Structural analysis of thin films}

Figure 1 shows the XRD patterns of ZnS thin films deposited by the thermal evaporation at room temperature in the thickness range $400-1300 \mathrm{~nm}$. Three peaks $\left(2 \theta=28.63^{\circ}, 47.63^{\circ}, 56.44^{\circ}\right)$ were importantly obtained for every film in the diffraction angle $(2 \theta)$ range from $20^{\circ}$ to $60^{\circ}$. This reveals that the nanocrystalline $\mathrm{ZnS}$ thin films were polycrystalline in nature with cubic structure. The planes in crystals were parallel to

Table 1. Experimental and standard " $d$ " values

\begin{tabular}{|c|c|c|c|}
\hline No. & $\begin{array}{c}(h k l) \\
\text { plane }\end{array}$ & $\begin{array}{c}\text { Experimental } d \\
\text { value }(\AA)\end{array}$ & $\begin{array}{c}\text { Standard } d \\
\text { value }(\AA)\end{array}$ \\
\hline 1 & 111 & 3.118 & 3.123 \\
2 & 220 & 1.911 & 1.912 \\
3 & 311 & 1.630 & 1.633 \\
\hline
\end{tabular}

the substrate surface. The cubic phase of the crystals was identified from the agreement of the peak position with standard JCPDS data card no. 65-1691. The nanocrystals of $\mathrm{ZnS}$ have planes (111), (220), and (311). Figure 1 also shows that the intensity of peaks was increased with the film thickness from 400 to $1300 \mathrm{~nm}$. This indicates that a full width half maximum (FWHM) of diffraction peaks decreases, as the film thickness increases. Due to this, the crystallinity of films is improved, and the particle size becomes larger, as the film thickness increases. The maximum grain size of about $97.89 \mathrm{~nm}$ and the minimum dislocation density $\left(0.10 \times 10^{15}\right.$ line $\left./ \mathrm{m}^{2}\right)$ were obtained for a film thickness of $1200 \mathrm{~nm}$. Thus, the crystallinity was improved with increase in the film thickness. The experimental and standard values for $\mathrm{ZnS}$ materials are presented in Table 1. The observed grain size and the dislocation density of thin films are summarized in Table 2.

From the EDAX measurements, thin films were non-stoichiometric with a composition of $\mathrm{Zn}=$ $=52.46 \%$ and $\mathrm{S}=47.54 \%$. Small differences between the compositions of $\mathrm{Zn}$ and $\mathrm{S}$ in fabricated thin films and the used source material were nearly $1 \%$.

The effect of the film thickness on the surface morphology of thin films was observed, by using SEM images (Fig. 2). It is clear from Fig. 2 that the fabricated thin films are homogeneous, without cracks and pin holes. The surface morphology of thin films was continuous and compact. The intermediate particle size varied in the range from 39.02 to $97.89 \mathrm{~nm}$. The crystallinity of the films increased, and the crystalline size along the crystal surface became larger, as the film thickness increased from 400 to $1300 \mathrm{~nm}$. The grain size has maximum (97.89 nm) for a film thickness of $1200 \mathrm{~nm}$, while the dislocation density $\left(0.10 \times 10^{15}\right.$ line $\left./ \mathrm{m}^{2}\right)$ has the lowest value. This is in good agreement with X-ray diffraction studies of thin films.

The variations of the particle size (nm) and the dislocation density of the fabricated semiconducting thin films with different thicknesses are shown in Fig. 3. It is clear from Fig. 3 that the grain size of films increased from $39.02 \mathrm{~nm}$ to $97.89 \mathrm{~nm}$ with the film thickness from 400 to $1300 \mathrm{~nm}$. The dislocation density decreased from $0.65 \times 10^{15}$ line $/ \mathrm{m}^{2}$ to $0.10 \times 10^{15}$ line $/ \mathrm{m}^{2}$ with thickness of films. The maximum grain size of $97.89 \mathrm{~nm}$ and the minimum dislocation density of $0.10 \times 10^{15}$ line $/ \mathrm{m}^{2}$ were obtained for a film thick- 

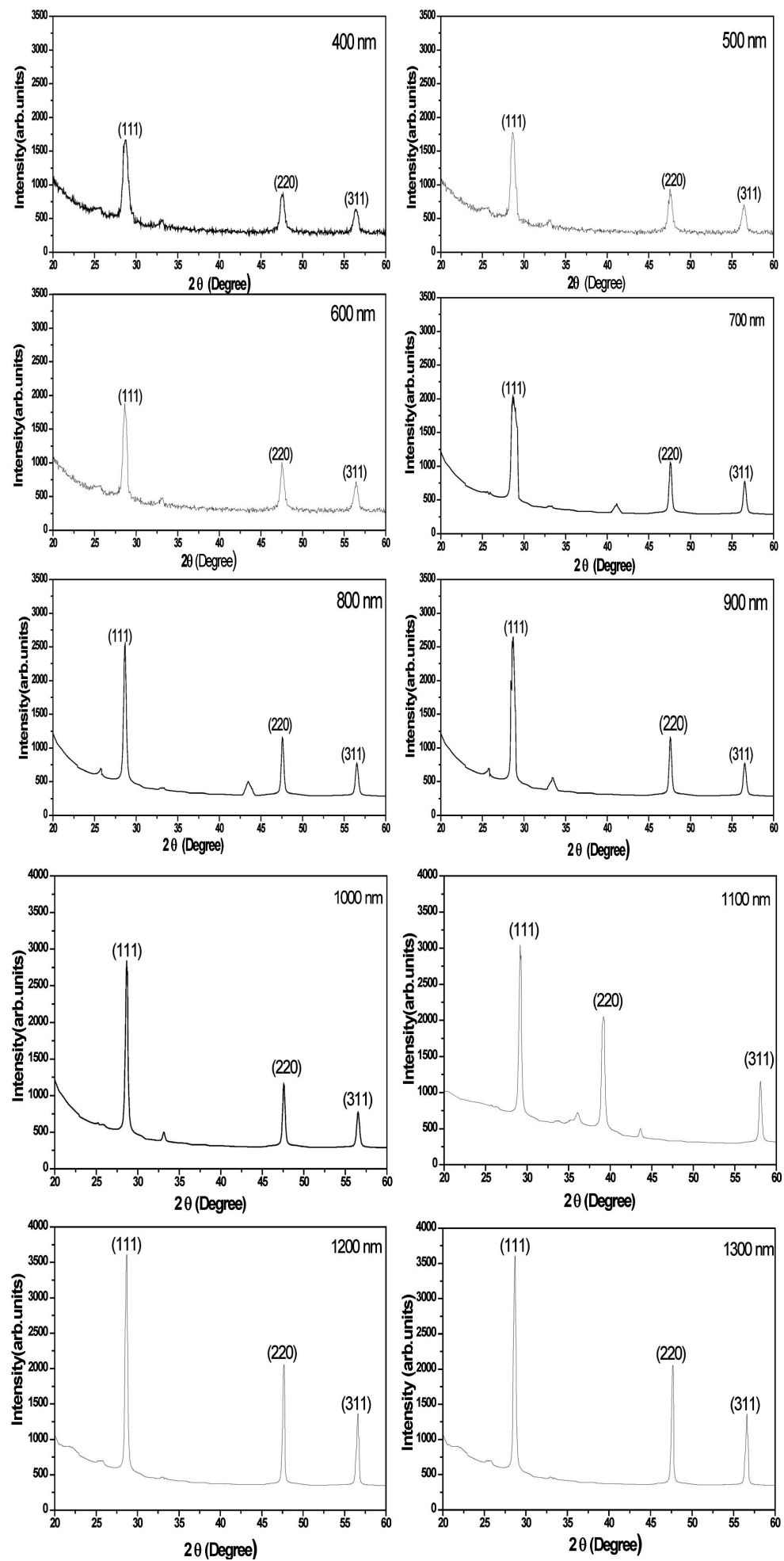

Fig. 1. X-ray diffraction patterns for films with different thicknesses (400$1300 \mathrm{~nm})$ 

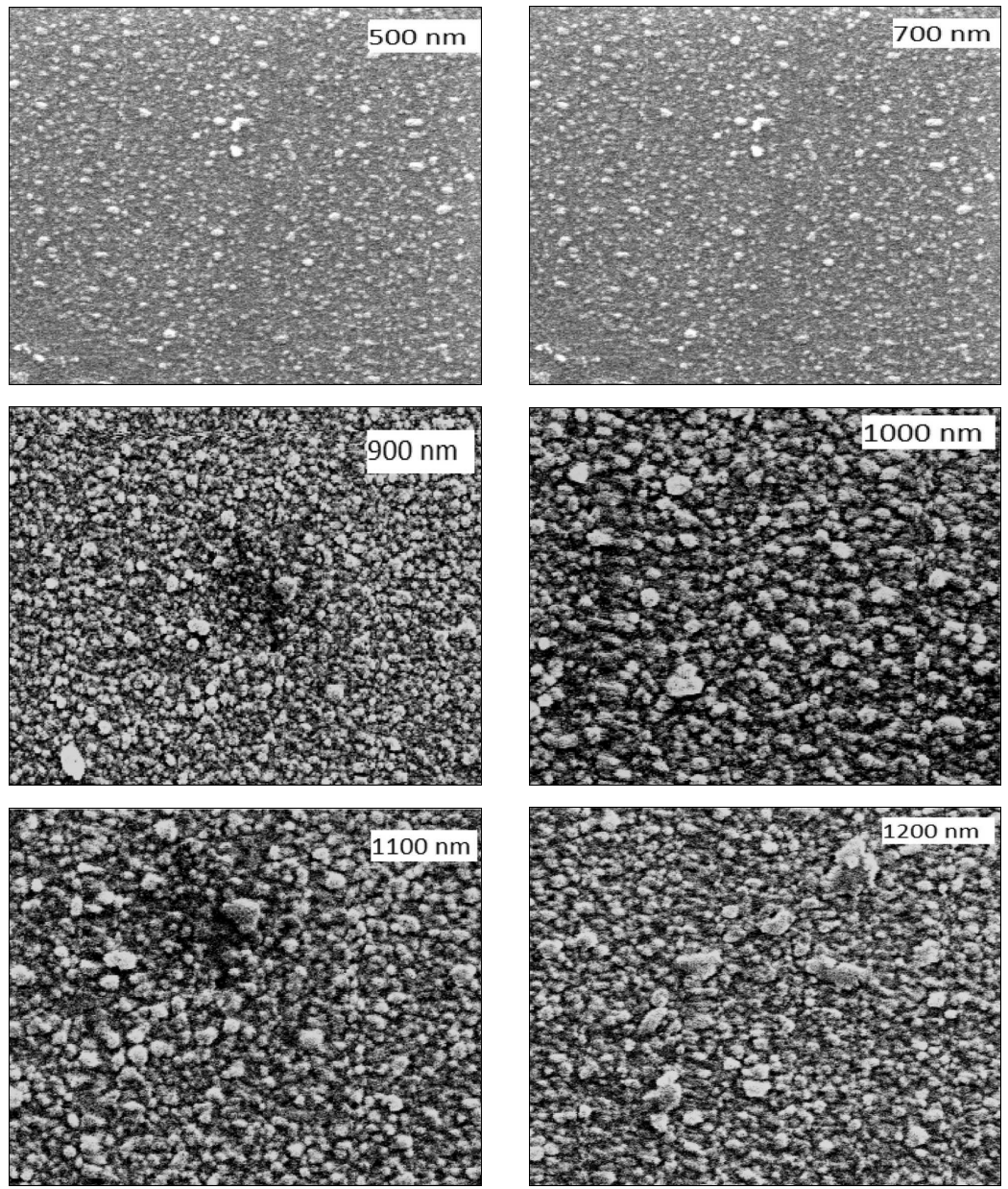

Fig. 2. Scanning electron micrographs of films with different thicknesses

Table 2. Structural, electrical, and optical parameters

\begin{tabular}{|c|c|c|c|c|c|c|c|}
\hline \multirow{2}{*}{$\begin{array}{l}\text { Film } \\
\text { thickness } \\
(\mathrm{nm})\end{array}$} & \multicolumn{2}{|c|}{ Structural parameters } & \multicolumn{4}{|c|}{ Electrical parameters } & \multirow{2}{*}{\begin{tabular}{|c|}
$\begin{array}{c}\text { Optical } \\
\text { parameters }\end{array}$ \\
$\begin{array}{c}\text { Band gap } \\
(\mathrm{eV})\end{array}$
\end{tabular}} \\
\hline & $\begin{array}{l}\text { Grain size } \\
\quad(\mathrm{nm})\end{array}$ & \begin{tabular}{|c|} 
Dislocation \\
density $\times 10^{15}$ line $/ \mathrm{m}^{2}$
\end{tabular} & $\begin{array}{c}\text { Resistivity } \times \\
\times 10^{6}(\mathrm{Ohm} \cdot \mathrm{cm})\end{array}$ & $\begin{array}{c}\text { Conductivity } \times \\
\times 10^{-6}(\mathrm{Ohm} \cdot \mathrm{cm})^{-1}\end{array}$ & $\begin{array}{c}\text { Mobility } \times \\
\times 10^{1} \mathrm{~cm}^{2} / \mathrm{V} \cdot \mathrm{s}\end{array}$ & $\begin{array}{c}\text { Activation } \\
\text { energy }(e V)\end{array}$ & \\
\hline 400 & 39.02 & 0.65 & 0.43 & 2.32 & 4.10 & 1.42 & 3.70 \\
\hline 500 & 52.64 & 0.36 & 0.36 & 2.77 & 7.60 & 1.26 & 3.64 \\
\hline 600 & 64.18 & 0.24 & 0.30 & 3.33 & 10.90 & 1.12 & 3.59 \\
\hline 700 & 73.96 & 0.18 & 0.24 & 4.16 & 14.80 & 1.03 & 3.55 \\
\hline 800 & 81.62 & 0.15 & 0.19 & 5.26 & 17.31 & 0.95 & 3.49 \\
\hline 900 & 88.34 & 0.12 & 0.15 & 6.66 & 19.90 & 0.88 & 3.42 \\
\hline 1000 & 92.34 & 0.11 & 0.11 & 9.09 & 22.92 & 0.81 & 3.35 \\
\hline 1100 & 95.56 & 0.10 & 0.09 & 11.11 & 24.61 & 0.76 & 3.31 \\
\hline 1200 & 97.89 & 0.10 & 0.08 & 12.50 & 26.03 & 0.73 & 3.26 \\
\hline 1300 & 97.88 & 0.10 & 0.08 & 12.50 & 25.80 & 0.74 & 3.27 \\
\hline
\end{tabular}


ness of $1200 \mathrm{~nm}$. At higher film thicknesses, the observed value of particle size reached a maximum saturation value, whereas the dislocation density takes minimal values. This indicates that the growth in grain size or particle size was constant above a thickness of $1200 \mathrm{~nm}$. The highest grain size of $97.89 \mathrm{~nm}$ indicates the highest conductivity and the lowest resistivity of films.

This improvement is due to the conglomeration of nanoparticles with one another and to a decrease in the number of crystal defects in thicker films. The maximum grain size of $97.89 \mathrm{~nm}$ and the minimum dislocation density of $0.10 \times 10^{15}$ line $/ \mathrm{m}^{2}$ were observed for the ZnS films fabricated at room temperature for a $1200 \mathrm{~nm}$ thick film, by using the thermal evaporation technique, whereas F. Haque et al. [25] reported the grain size of $34.08 \mathrm{~nm}$ and the dislocation density of $0.86 \times 10^{15}$ line $/ \mathrm{m}^{2}$ for $\mathrm{ZnS}$ thin films produced by the magnetron sputtering. J.P. Borah et al. [26] reported the grain size of $7.0 \mathrm{~nm}$ for a $\mathrm{ZnS}$ crystal by the chemical route method, and R. Chauhan et al. [27] and S.W. Lu et al. [28] reported grain sizes of $4.0 \mathrm{~nm}$ and $3.0 \mathrm{~nm}$, respectively, for $\mathrm{ZnS}$ nanoparticles produced by the chemical precipitation method.

\subsection{Electrical analysis of thin films}

The calculated values of the electrical resistivity, conductivity, mobility of charge carriers, and activation energy of thin films fabricated by the thermal evaporation are given in Table 2. It is clear from Table 2 that the electrical resistivity decreases, while the conductivity increases with the film thickness. This shows that the films are semiconductors in nature. The reduction in electrical resistivity or improvement in conductivity is due to the improvement in the crystallinity of a film with increase in its thickness. The variations of electrical resistivity and conductivity of thin films with film thickness are represented in Fig. 4. It is clear from Fig. 4 that the electrical resistivity decreases from $0.43 \times 10^{6}$ to $0.08 \times 10^{6}$ $\mathrm{Ohm} \cdot \mathrm{cm}$, as the film thickness increases from 400 to $1300 \mathrm{~nm}$. The electrical conductivity increases from $2.32 \times 10^{-6}$ to $12.50 \times 10^{-6}(\mathrm{Ohm} \cdot \mathrm{cm})^{-1}$ with the film thickness increased from 400 to $1300 \mathrm{~nm}$. These obtained results represent that there semiconducting behavior of films increases with the film thickness. The Hall effect observations show that the films exhibit the $n$-type semiconductivity. Figure 5 shows that the

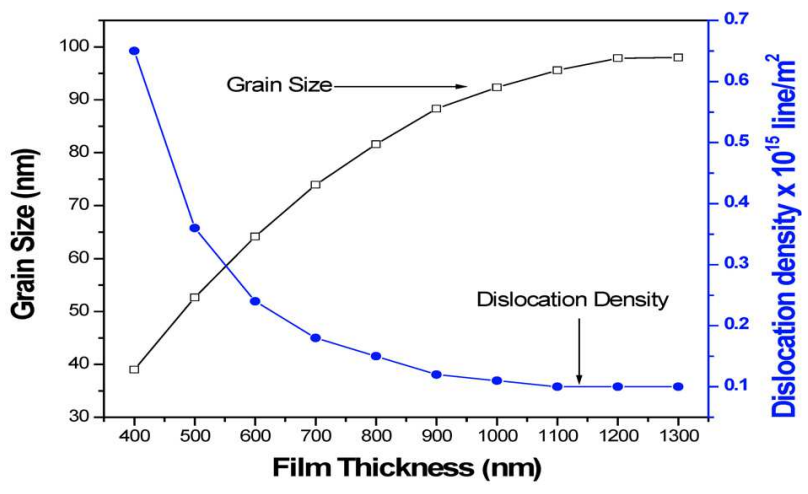

Fig. 3. Variations of the grain size and the dislocation density with film thickness

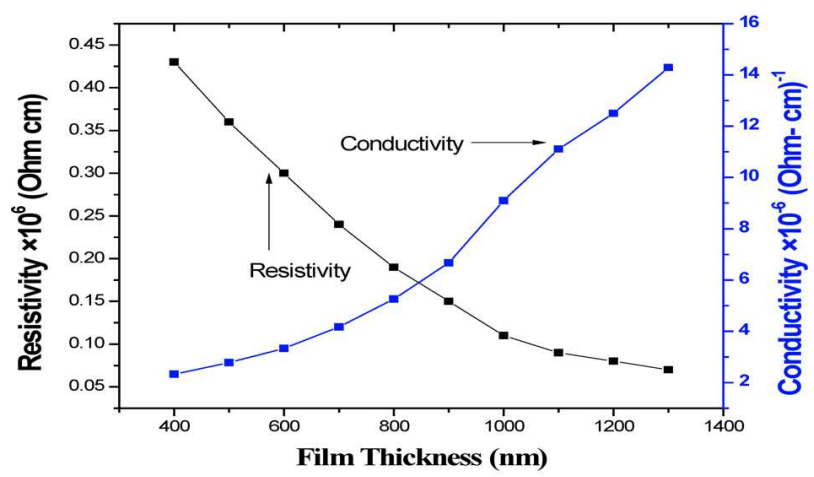

Fig. 4. Variations of the resistivity and the conductivity of films with different thicknesses

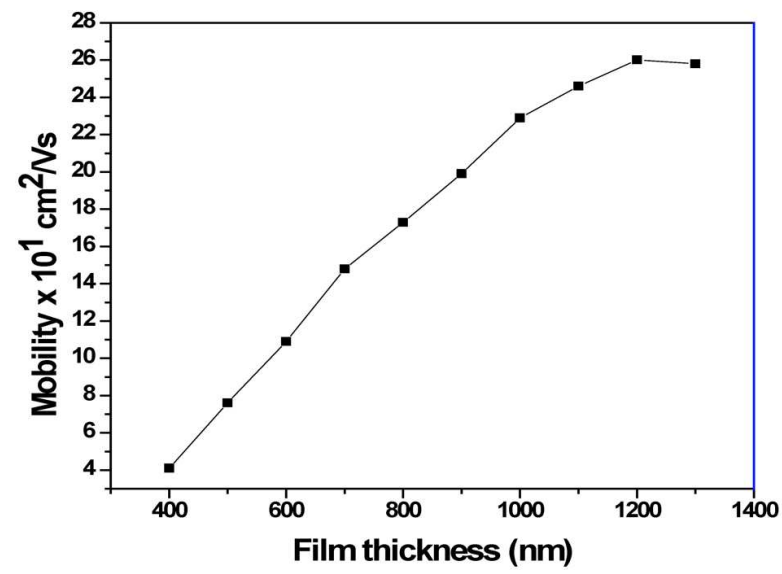

Fig. 5. Variation of the mobility of charge carriers for different film thicknesses

dependence of the electron mobility on the film thickness at room temperature. It is seen from Fig. 5 that, as the film thickness increases, the mobility of electrons increases and takes the maximum value of 


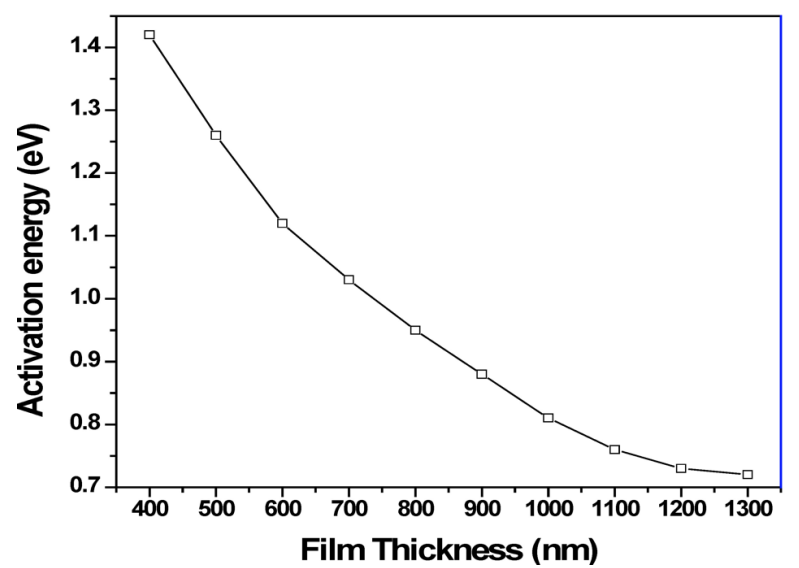

Fig. 6. Variation of the activation energy for different film thicknesses

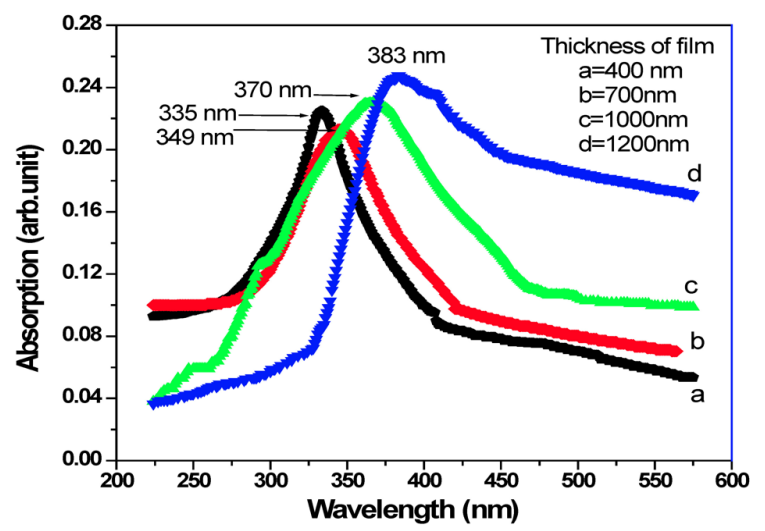

Fig. 7. Absorption versus the wavelength at different film thicknesses: $400 \mathrm{~nm}(a) 700 \mathrm{~nm}(b), 1000 \mathrm{~nm}(c), 1200 \mathrm{~nm}(d)$

$26.03 \times 10^{1} \mathrm{~cm}^{2} / \mathrm{V} \cdot \mathrm{s}$ for a $1200 \mathrm{~nm}$ thick film. The decrement in the electrical resistivity and increments in the conductivity and the mobility of charge carriers are due to an improvement in the crystallinity of thin films with increase in the film thickness. This may be also due to a decrease in the lattice mismatch or grain boundary scattering [29]. The minimum electrical resistivity of $0.08 \times 10^{6}(\mathrm{Ohm} \cdot \mathrm{cm})$, high electrical conductivity of $12.50 \times 10^{-6}(\mathrm{Ohm} \cdot \mathrm{cm})^{-1}$, and electron mobility of $26.0 \times 10^{1} \mathrm{~cm}^{2} / \mathrm{V} \cdot \mathrm{s}$ were obtained for the 1200-nm film thickness at room temperature. The values of electrical resistivity, conductivity, and mobility of thin films are nearly saturated above the 1200-nm thickness. This may be due to an increment in the grain size with the film thickness.
The activation energies of semiconducting $\mathrm{ZnS}$ thin films were determined from the slope of log of the resistivity $(\log \rho)$ versus the reciprocal temperature $(1 / T) \times 10^{3} \mathrm{~K}$. The variation of the activation energy for different film thicknesses is shown in Fig. 6. It is clear from Fig. 6 that the activation energy decreases from $1.42 \mathrm{eV}$ to $0.73 \mathrm{eV}$ with increase in the film thickness from 400 to $1300 \mathrm{~nm}$. Nearly above the 1200-nm thickness, the value of activation energy is saturated. This may be due to that the distance between the valence and conduction bands decreases with increase in the film thickness from $400 \mathrm{~nm}$ to $1300 \mathrm{~nm}$. Above the 1200-nm thickness, the activation energy is constant. A shift of the activation energy leads to a change of the level of degeneracy of the conduction band in thin films, as the thickness of a film varies. The reduced activation energy in films shows the trapping of the Fermi level from the valence band to the conduction band [30]. The minimum activation energy $0.73 \mathrm{eV}$ was obtained for a $1200-\mathrm{nm}-$ thickness film.

The lowest resistivity of $0.08 \times 10^{6} \mathrm{Ohm} \cdot \mathrm{cm}$, highest electrical conductivity of $6.66 \times 10^{-6}(\mathrm{Ohm} \times$ $\times \mathrm{cm})^{-1}$, and electron mobility of $26.0 \times 10^{1} \mathrm{~cm}^{2} / \mathrm{V} \cdot \mathrm{s}$ were observed for a film $1200 \mathrm{~nm}$ in thickness, by using the thermal evaporation technique, whereas A.U. Ubale et al. [23] reported the resistivity of $0.18 \times 10^{6} \mathrm{Ohm} \cdot \mathrm{cm}$ and activation energy of $1.29 \mathrm{eV}$ for $\mathrm{ZnS}$ thin films deposited by the chemical bath technique. F. Haque et al. [25] reported the electron mobility of $23.5 \times 10^{1} \mathrm{~cm}^{2} / \mathrm{V} \cdot \mathrm{s}$ for $\mathrm{ZnS}$ film deposited by the magnetron sputtering. F. Ozutok et al. [31] reported the resistivity of $0.49 \times 10^{6} \mathrm{Ohm} \cdot \mathrm{cm}$ and conductivity of $2.05 \times 10^{-6}(\mathrm{Ohm} \cdot \mathrm{cm})^{-1}$ for a $\mathrm{ZnS}$ thin film deposited by the spray pyrolysis technique. M.S. Shinde et al. [32] reported the activation energy of $0.89 \mathrm{eV}$ for a $\mathrm{ZnS}$ film deposited by the chemical bath deposition.

\subsection{Optical analysis of thin films}

The optical absorption spectra of ZnS thin films deposited at room temperature with thicknesses of 400 , 700,1000 , and $1200 \mathrm{~nm}$ were measured in the wavelength range $200-600 \mathrm{~nm}$ by an UV-Vis spectrophotometer and are presented in Fig. 7. It is clear from Fig. 7 that the optical absorption increases with the wavelength till $383 \mathrm{~nm}$. Above it, the absorption decreases. The optical absorption also increases with 
the film thickness, because the grain boundary scattering is reduced with increase in the film thickness. The absorption peaks appeared in the UV spectra at different wavelengths are 335, 349, 370, and $383 \mathrm{~nm}$ for thin films with thicknesses of 400, 700, 1000 , and $1200 \mathrm{~nm}$, respectively. It is also observed that the absorption peak shifts toward longer wavelengths with increase in the film thickness. This represents a decrease in the band gap, as the film thickness increases. The absorbance increases with the film thickness. This may be due to that the thicker films have more atoms; so, more states will be available for the photons to be absorbed. There is a small absorption above the 450-nm wavelength. These small absorption peaks indicate that few states are generated in the region between the valence and conduction bands. These states may be related to some lattice defects in the films.

It can be seen that the strongest absorption peak is revealed by the film $1200 \mathrm{~nm}$ in thickness. This absorption, which corresponds to the transmission from the valence band to conduction one, is used to determine the energy band gap. The fabricated $\mathrm{ZnS}$ film has a good absorption for light in the wavelength range 250-450 $\mathrm{nm}$ [27].

The variation of $(\alpha h \nu)^{2}$ with the photon energy $(\mathrm{eV})$ is shown in Fig. 8. The extrapolation of the straight-line portion of the plot gives the value of direct band gap. Using these spectra, we determined the band gap of ZnS thin films. As specified in Fig. 8, the band gaps of the deposited ZnS films of 400, 700, 1000 , and $1200 \mathrm{~nm}$ in thickness are 3.70, 3.55, 3.35, and $3.26 \mathrm{eV}$, respectively. The minimum band gap of $3.26 \mathrm{eV}$ is obtained for a film $1200 \mathrm{~nm}$ in thickness. This shows that the band gap of thin films decreases with increase in the film thickness. The band gap of a 1200-nm film is closer to that of the bulk cubic phase $(3.5 \mathrm{eV})$ and a single $\mathrm{ZnS}$ crystal $(3.6 \mathrm{eV})$.

The minimum direct band gap equal to $3.26 \mathrm{eV}$ was observed for a 1200-nm-thick ZnS film fabricated with the use of the thermal evaporation at room temperature. M.S. Shinde et al. [32] reported the band gap of $3.51 \mathrm{eV}$ for ZnS thin films deposited by the chemical bath deposition. P. Kumar et al. [33] reported the band gap of $3.50 \mathrm{eV}$ for a $\mathrm{ZnS}$ thin film produced by the vacuum evaporation technique. H.R. Dizaji et al. [34] reported the band gap of $3.45 \mathrm{eV}$ for a $\mathrm{ZnS}$ thin film deposited by flash evaporation technique. D.H. Hwang et al. [35] reported the band gap

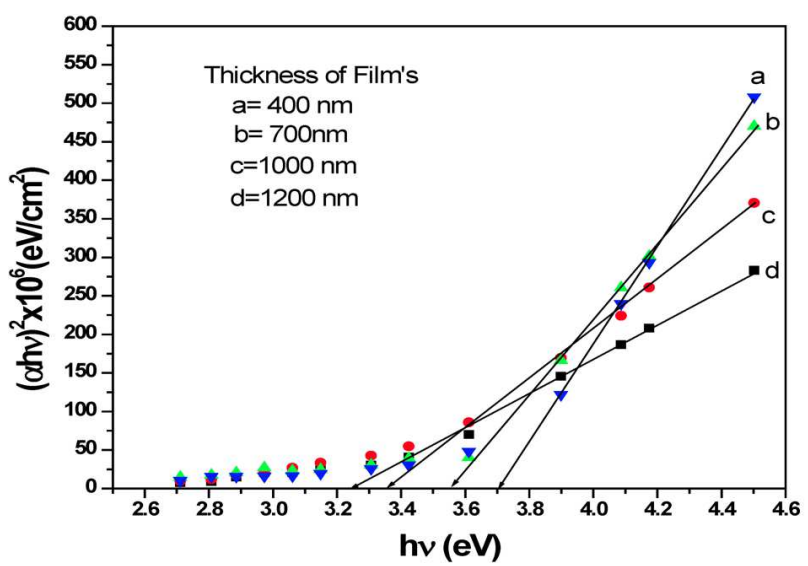

Fig. 8. $(\alpha h \nu)^{2}$ versus the photon energy at different film thicknesses

of $3.79 \mathrm{eV}$ for a $\mathrm{ZnS}$ thin film obtained by the magnetron sputtering.

The film $1200 \mathrm{~nm}$ in thickness was optimal due to the highest grain size of $97.89 \mathrm{~nm}$, electron mobility of $26.03 \times 10^{1} \mathrm{~cm}^{2} / \mathrm{V} \cdot \mathrm{s}$, conductivity of $12.50 \times$ $\times 10^{-6}(\mathrm{Ohm} \cdot \mathrm{cm})^{-1}$, lowest dislocation density of $0.10 \times 10^{15}$ line $/ \mathrm{m}^{2}$, resistivity of $0.08 \times 10^{6} \mathrm{Ohm} \cdot \mathrm{cm}$, activation energy of $0.73 \mathrm{eV}$, and band gap of $3.26 \mathrm{eV}$. The studies of the structural, electrical, and optical properties of deposited films support a decrease in the resistivity due to an improvement in their crystallinity, which would increase the mobility of charge carriers and would lower the defect levels, as the film thickness increases.

\section{Conclusion}

The semiconducting $\mathrm{ZnS}$ thin films with different thicknesses are successfully deposited on a glass substrate, by using the thermal evaporation technique at room temperature. The maximum grain size of $97.89 \mathrm{~nm}$ was obtained from XRD measurements. SEM shows the agglomeration of nanocrystals without pin holes. The XRD analysis shows that films have cubic structure. The minimum resistivity of $0.08 \times 10^{6}(\mathrm{Ohm} \cdot \mathrm{cm})$, maximum conductivity of $12.50 \times 10^{-6}(\mathrm{Ohm} \cdot \mathrm{cm})^{-1}$, and highest mobility of $26.03 \times 10^{1} \mathrm{~cm}^{2} / \mathrm{V} \cdot \mathrm{s}$ were obtained for a $1200-\mathrm{nm}-$ thick film. The measurement of optical absorption spectra indicates that the band gap decreases, as the film thickness increases. The minimum band gap of $3.26 \mathrm{eV}$ is observed. A thickness of $1200 \mathrm{~nm}$ is optimal. 
I am thankful to the Institute for providing XRD and SEM facilities. I am also grateful to my colleagues for their help in the preparation of thin films.

1. L. Li-ping, Q. Xiao-qing, L. Guang-she. Correlation between size-induced lattice variations and yellow emission shift in $\mathrm{ZnO}$ nanostructures. Applied Physics Letters $\mathbf{8 7}$, 124101 (2005).

2. H.M. Schmidt, H. Weller. Synthesis of $\mathrm{ZnS}$ nano particles by solid liquid chemicals method. Chemical Physics Letters 129, 615 (1986).

3. S.Y. Yuan, Y. Juan, Q.K. Qiang. Synthesis of ZnS nanoparticales by chemical reaction with $\mathrm{ZnO}$ and $\mathrm{Na}_{2} \mathrm{~S}$ under ultrasonic. Trans. Nonferrous Met. Soc. China 20, 211 (2010).

4. C. Xing-wang, L. Xiang, Z. Fei-fei, Y. Zhou, L. Xue, L. Peng-ting. Fabrication and photoluminescence study on $\mathrm{ZnO}$ nanostructured particles. J. of Aeronautical Materials 29, 92 (2009).

5. Y.Y. Chen, J.G. Duh, B.S. Chiou, C.G. Peng. Luminescent mechanism of $\mathrm{ZnS}: \mathrm{Cu}: \mathrm{Cl}$ and $\mathrm{ZnS}: \mathrm{Cu}: \mathrm{Al}$ phosphors. Thin Solid Films 392, 50 (2001).

6. K. Benyahia, A. Benhaya, M.S. Aida. ZnS thin films deposited by thermal evaporation for photovoltaic applications. J. of Semiconductors 36, 103001 (2015).

7. H. Cho, C. Yun, J.W. Park, S. Yoo. Highly flexible organic light emitting diodes based on $\mathrm{ZnS} / \mathrm{Ag} / \mathrm{Wo}_{3}$ multilayers transparent electrodes. Organic Electronics 10, 1163 (2009).

8. X. Liu, X. Cai, J. Mao, C. Jin. ZnS/Ag/ZnS nano multilayer films for transparent electrodes in flat display application. Applied Surface Science 183, 103 (2001).

9. F. Karuna, Y.H. Ng, Y. Tang, R. Amal, N. Valanoor, J. Hart. ZnS thin film for visible light active photoelectrode: Effect of film morphology and crystal structure. Cryst. Growth Des. 16, 2461 (2016).

10. V. Dimitrova, J. Tate. Synthesis and characterization of some ZnS-based thin film phosphors for electroluminescent device applications. Thin Solid Films 365, 134 (2000).

11. E. Katz, I. Willner. Nanotechnology Concept (Wiley-VCH, 2004), Chapter 14, 200.

12. A. Nitta, K. Tanakab, Y. Maekawab, M. Kusabirakib, M. Aozasa. Effects of gas impurities in the sputtering environment on the stoichiometry and crystallinity of $\mathrm{ZnS}: \mathrm{Mn}$ electroluminescent-device active layers. Thin Solid Films 384, 261 (2001).

13. S. Yano, R. Schroeder, B. Ullrich, H. Sakai. Absorption and photocurrent properties of thin $\mathrm{ZnS}$ films formed by pulsed-laser deposition on quartz. Thin Solid Films 423, 273 (2003).

14. Q.J. Feng, D.Z. Shen, J.Y. Zhang, H.W. Liang, D.X. Zhao, Y.M. Lua, X.W. Fan. Highly aligned ZnS nanorods grown by plasma-assisted metalorganic chemical vapor deposition. J. Crystal Growth 285, 561 (2005).
15. Z. Zhang, D.Z. Shen, J.Y. Zhang, C.X. Shan, Y.M. Lu, Y.C. Liu, B.H. Li, D.X. Zhao, B. Yao, X.W. Fan. The growth of single cubic phase $\mathrm{ZnS}$ thin films on silica glass by plasma-assisted metalorganic chemical vapor deposition. Thin Solid Films 513, 114 (2006).

16. M. Gunasekaran, R. Gopalakrishnan, P. Ramasamy. Deposition of $\mathrm{ZnS}$ thin films by photochemical deposition technique. Mater. Lett. 58, 67 (2003).

17. X.T. Zhang, Y.C. Liu, L.G. Zhang, J.Y. Zhang, Y.M. Lu, D.Z. Shen, W.X.u, G.Z. Zhong, X.W. Fan, Z.G. Kong. Photoluminescence and optically pumped ultraviolet lasing from nanocrystalline $\mathrm{ZnO}$ thin films prepared by thermal oxidation of high-quality $\mathrm{ZnS}$ thin films. Chin. Phys. Lett. 19, 127 (2002).

18. S. Wang, X. Fu, G. Xia, J. Wang, J. Shao, Z. Fan. Structure and optical properties of $\mathrm{ZnS}$ thin films grown by glancing angle deposition. Appl. Surf. Sci. 252, 8734 (2006).

19. N. Fathy, R. Kobayashi. M. Ichimura. Preparation of ZnS thin films by the pulsed electrochemical deposition. Mater. Sci. Eng. B 107, 271 (2004).

20. P. Roy, J.R. Ota, S.K. Srivastava. Crystalline ZnS thin films by chemical bath deposition method and its characterization. Thin Solid Films 515, 1912 (2006).

21. S.P. Patel, D. Kanjilal, L. Kumar. Nano patterning of ZnS thin surfaces by $\mathrm{keV}$ ion beam irradiation. Surface \& Coatings Technology 206, 487 (2011).

22. V. Ramasamy, K. Praba, G. Murugadoss. Study of optical and thermal properties in nickel doped $\mathrm{ZnS}$ nanoparticles using surfactants. Superlattices and Microstructures 51, 699 (2012).

23. A.U. Ubale, D.K. Kulkarni. Preparation and study of thickness dependent electrical characteristics of zinc sulfide thin films. Bull. Mater. Sci. 28, 43 (2005).

24. A. Cottrell. An Intorduction to Metallurgy (Hodder Arnold, 1975), p. 173-178 [ISBN: 0713125101].

25. F. Haque, K.S. Rahman, M.A. Islam, M.J. Rasid, M.M. Alam, Z.A. Alothman, K. Soplan, N. Amin. Growth optimization of $\mathrm{ZnS}$ thin films by R.F. Magnetron sputtering as prospective buffer layer in thin film solar cell. Chalcogenide Letters 11, 189 (2014).

26. J.P. Borah, J. Barman, K.C. Sarma. Structural and optical properties of $\mathrm{ZnS}$ nanoparticles. Chalcogenide Letters $\mathbf{5}$, 201 (2008).

27. R. Chauhan, A. Kumar, R.P. Chaudhary. Characterization of chemically synthesized Mn doped $\mathrm{ZnS}$ nanoparticals. Chalcogenide Letters 9, 151 (2012).

28. S.W. Lu, B.I. Lee, Z.L. Wang, W. Tong, B.K. Wagner, W. Park, C.J. Summers. Synthesis and photoluminescence enhancement of $\mathrm{Mn}$ doped $\mathrm{ZnS}$ nanocrystals. J. of Luminensence 92, 73 (2001).

29. S.R. Vishwakarma, A. Kumar, R.S.N. Tripathi, Rahul S. Das. Fabrication and characterization of $n-\mathrm{InSb}$ thin film of different thicknesses. Indian J. of Pure EG Applied Physics 51, 260 (2013).

ISSN 2071-0194. Ukr. J. Phys. 2017. Vol. 62, No. 5 
30. Y.Y. Bacherikov, S.Y. Zelensky, A.G. Zhuk, N.A. Semenenko, O.S. Krylova. Luminescent properties of finedispersed $\mathrm{ZnS}: \mathrm{Cu}$ prepared using self-propagating hightemperature synthesis. Semiconductor Physics, Quantum Electronics \&5 Optoelectronics 17, 374 (2014).

31. F. Ozutok, K. Erturk, V. Bilgin. Growth, electrical and optical properties of $\mathrm{ZnS}: \mathrm{Mn}$ thin films. Acta Physica Polonica A 121, 221 (2012).

32. M.S. Shinde, P.B. Ahirrao, I.J. Patil, R.S. Patil. Studies on nanocrystalline $\mathrm{ZnS}$ thin films prepared by modified chemical bath deposition method. Indian J. Pure $\mathscr{E}$ Appl. Phys. 49, 765 (2011).

33. P. Kumar, A. Kumar, P.N. Dixit, T.P. Sharma. Optical, structural and electrical properties of zinc sulfide vacuum evaporated thin films. Indian J. Pure $\&$ Appl. Phys 44, 690 (2006).

34. H.R. Dizaji, A.J. Zavaraki, M.H. Ehsani. Effect of thickness on the structural and optical properties of $\mathrm{ZnS}$ thin films prepared by flash evaporation technique equipped with modified feeder. Chalocogenide Letters 8, 231 (2011).

35. D.H. Hwang, J.H. Ahn, K.N. Hui, Y.G. Son. Structural and optical properties of $\mathrm{ZnS}$ thin films deposited by $\mathrm{RF}$ magnetron sputtering. Nanoscale Research Letters 7, 26 (2012).

Received 01.09.16

\section{P. Вішвакарма}

\section{ЗАЛЕЖНІСТЬ ВІД ТОВЩИНИ}

СТРУКТУРНИХ, ЕЛЕКТРИЧНИХ І ОПТИЧнИХ

ВЛАСТИВОСТЕЙ ZnS ТОНКИХ ПЛІВОК, ОСАДЖЕНИХ ТЕРМІЧНИМ ВИПАРОВУВАННЯМ

\section{$\mathrm{P}$ е $з$ ю м е}

Тонкі плівки ZnS осаджені методом термічного випаровування при кімнатній температурі на скляну підкладку, очищену ультразвуком. Товщина плівок змінювалася від 400 до 1300 нм. Структуру плівок досліджено за допомогою рентгеноструктурного аналізу, растрової електронної мікроскопії (SEM) і рентгенівського дисперсійного аналізу. Електричні і оптичні властивості вимірювалися двоточечним зондом на постійному струмі, за ефектом Холла і за спектрами поглинання у видимому і ультрафіолетовому світлі. Рентгенівські спектри показали, що плівки полікристалічні і мають кубічну структуру з переважаючою (111) орієнтацією. Дифракційні картини стають різкішими з ростом товщини плівок. За даними SEM розмір нанозерен плівок близько 97,89 нм. Зменшення опору свідчить про напівпровідникову природу плівок. У плівок з товщиною понад 1200 нм максимальна рухливість дорівнює $26,03 \cdot 10^{1} \mathrm{~cm}^{2} / \mathrm{B} \cdot \mathrm{c}$, мінімальний опір $0,08 \cdot 10^{6}(\mathrm{Oм} \cdot \mathrm{cm})$ і ширина забороненої зони 3,26 eВ. 3 урахуванням цих властивостей знайдено оптимальну товщину плівок. 